\title{
Lung Soft Tissue Neoplasm
}

National Cancer Institute

\section{Source}

National Cancer Institute. Lung Soft Tissue Neoplasm. NCI Thesaurus. Code C45612.

A benign, intermediate, or malignant mesenchymal neoplasm that arises from the lung. 